Prepared in cooperation with the Great Plains Landscape Conservation Cooperative, U.S. Fish and Wildlife Service, Albuquerque, New Mexico

\title{
Landsat Classification of Surface-Water Presence During Multiple Years to Assess Response of Playa Wetlands to Climatic Variability Across the Great Plains Landscape Conservation Cooperative Region
}

Open-File Report 2017-1166 



\section{Landsat Classification of Surface-Water Presence During Multiple Years to Assess Response of Playa Wetlands to Climatic Variability Across the Great Plains Landscape Conservation Cooperative Region}

By Daniel J. Manier and Jennifer R. Rover

Prepared in cooperation with the Great Plains Landscape Conservation

Cooperative, U.S. Fish and Wildlife Service, Albuquerque, New Mexico

Open-File Report 2017-1166 


\title{
U.S. Department of the Interior \\ RYAN K. ZINKE, Secretary
}

\section{U.S. Geological Survey William H. Werkheiser, Deputy Director exercising the authority of the Director}

\author{
U.S. Geological Survey, Reston, Virginia: 2018
}

For more information on the USGS - the Federal source for science about the Earth, its natural and living resources, natural hazards, and the environment-visit https://www.usgs.gov or call 1-888-ASK-USGS.

For an overview of USGS information products, including maps, imagery, and publications, visit https://store.usgs.gov.

Any use of trade, firm, or product names is for descriptive purposes only and does not imply endorsement by the U.S. Government.

Although this information product, for the most part, is in the public domain, it also may contain copyrighted materials as noted in the text. Permission to reproduce copyrighted items must be secured from the copyright owner.

Suggested citation:

Manier, D.J., and Rover, J.R., 2018, Landsat classification of surface-water presence during multiple years to assess response of playa wetlands to climatic variability across the Great Plains Landscape Conservation Cooperative region: U.S. Geological Survey Open-File Report 2017-1166, 20 p., https://doi.org/10.3133/ofr20171166.

ISSN 2331-1258 (oline) 


\section{Contents}

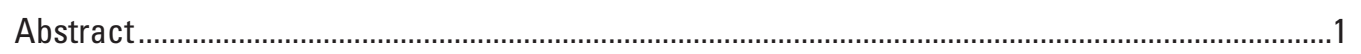

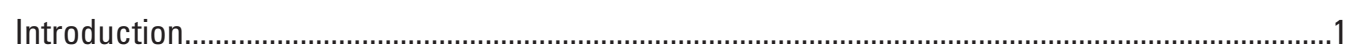

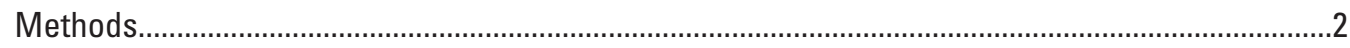

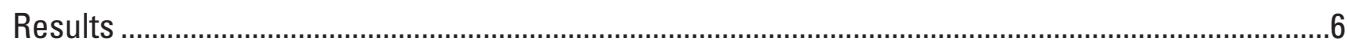

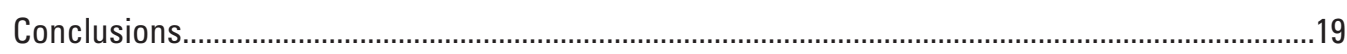

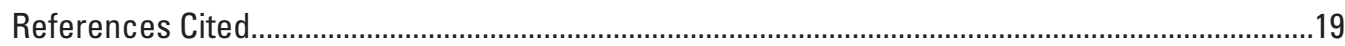

\section{Figures}

1. Distribution of Landsat scenes (Landsat path-row footprints) used to observe surface water across the Great Plains Landscape Conservation Cooperative.

2. Close-up view of north Texas, east of Amarillo, showing surface water from Landsat classification and probable playas.

3. National Drought Mitigation Center summaries of climate-induced moisture indicating drought conditions, for 6-month periods, January-June, for 4 different years .

4. Frequency-distribution plot of playa surface-area estimates for 1989, 1996, 2004, and 2008

5. Map showing the distribution of surface water and probable playas in the Great Plains Landscape Conservation Cooperative in the springs of 1989, 1996, 2004, and 2008.

6. Map showing the distribution of surface water and probable playas in the Great Plains Landscape Conservation Cooperative in the spring of 1989.

7. Map showing the distribution of surface water and probable playas in the Great Plains Landscape Conservation Cooperative in the spring of 1996.

8. Map showing the distribution of surface water and probable playas in the Great Plains Landscape Conservation Cooperative in the spring of 2004

9. Map showing the distribution of surface water and probable playas in the Great Plains Landscape Conservation Cooperative in the spring of 2008

10. Map showing an enlarged view of the distribution of surface water and probable playas in part of Texas, within the Great Plains Landscape Conservation Cooperative in the spring of 2008 .

11. Map showing a view even more enlarged than that of figure 10 , showing the distribution of surface water and probable playas in the Great Plains Landscape Conservation Cooperative in the spring of 2008.

12. Map showing an enlarged view of a distribution of surface water and probable playas in part of eastern Nebraska within the Great Plains Landscape Conservation Cooperative, in the spring of 2008 


\section{Tables}

1. Summary of Landsat-based classifications of the occurrence of surface water within probable playas across the Great Plains Landscape Conservation

Cooperative.

2. Summary of playas that held any amount of water during the evaluation years, based on the count of probable playa locations with water signatures in Landsat classifications ...

3. Percent of area defined in the probable playas datasets covered by water according to Landsat surface water classification for each state and year.

4. Assessment of precipitation patterns using the Standardized Precipitation Index for climate divisions (geographic areas) within the boundary of the Great Plains Landscape Conservation Cooperative

\section{Conversion Factors}

International System of Units to U.S. customary units

\begin{tabular}{lcl}
\hline & Multiply & \multicolumn{1}{c}{ To obtain } \\
\hline & Length & \\
\hline meter $(\mathrm{m})$ & 3.281 & foot $(\mathrm{ft})$ \\
meter $(\mathrm{m})$ & 1.094 & yard $(\mathrm{yd})$ \\
\hline & Area & \\
\hline square meter $\left(\mathrm{m}^{2}\right)$ & 0.0002471 & acre \\
square meter $\left(\mathrm{m}^{2}\right)$ & 10.76 & square foot $\left(\mathrm{ft}^{2}\right)$ \\
hectare (ha) & 2.471 & acre \\
hectare (ha) & 0.003861 & square mile $\left(\mathrm{mi}^{2}\right)$ \\
\hline
\end{tabular}




\title{
Landsat Classification of Surface-Water Presence During Multiple Years to Assess Response of Playa Wetlands to Climatic Variability Across the Great Plains Landscape Conservation Cooperative Region
}

\author{
By Daniel J. Manier and Jennifer R. Rover
}

\begin{abstract}
To improve understanding of the distribution of ecologically important, ephemeral wetland habitats across the Great Plains, the occurrence and distribution of surface water in playa wetland complexes were documented for four different years across the Great Plains Landscape Conservation Cooperative (GPLCC) region. This information is important because it informs land and wildlife managers about the timing and location of habitat availability. Data with an accurate timestamp that indicate the presence of water, the percent of the area inundated with water, and the spatial distribution of playa wetlands with water are needed for a host of resource inventory, monitoring, and research applications. For example, the distribution of inundated wetlands forms the spatial pattern of available habitat for resident shorebirds and water birds, stop-over habitats for migratory birds, connectivity and clustering of wetland habitats, and surface waters that recharge the Ogallala aquifer; there is considerable variability in the distribution of playa wetlands holding water through time. Documentation of these spatially and temporally intricate processes, here, provides data required to assess connections between inundation and multiple environmental drivers, such as climate, land use, soil, and topography. Climate drivers are understood to interact with land cover, land use and soil attributes in determining the amount of water that flows overland into playa wetlands. Results indicated significant spatial variability represented by differences in the percent of playas inundated among States within the GPLCC. Further, analysis-of-variance comparison of differences in inundation between years showed significant differences in all cases. Although some connections with seasonal moisture patterns may be observed, the complex spatial-temporal gradients of precipitation, temperature, soils, and land use need to be combined as covariates in multivariate models to effectively account for these patterns. We demonstrate the feasibility of using classification of Landsat satellite imagery to describe playa-wetland inundation across years and seasons. Evaluating classifications representing only 4 years of imagery, we found significant year-to-year and state-to-state differences in inundation rates.
\end{abstract}

\section{Introduction}

Conservation of playa wetlands is important for the wildlife and hydrology of the Great Plains region, and understanding patterns and determinants of inundation (flooding) of these wetlands is important for conservation (Bartuszevige and others, 2012). Understanding the distribution of playa wetlands is important for determining and monitoring the condition of wetland habitats distributed across much of the Central North American flyway, which is the trans-continental route for thousands of migratory waterfowl and shorebirds as well as habitat for resident waterfowl and shorebirds, making these wetlands essential habitats for wildlife conservation. Playa wetlands are fed by surface water provided by precipitation in the watershed. Due to the highly variable provision of precipitation and the effects of variable soil conditions and air temperatures, inundation of playa wetlands is highly variable across the landscape and over time. In addition, land use within the watershed and alterations to soil profiles, such as pitting (manual deepening of playas), can have important effects on surface hydrology of the watershed and hydrologic cycles of playa wetlands. Therefore, only a small percentage of the multitude of potential wetland locations meet the landscape, weather, and climate conditions required for inundation each year. The locations of more than 80,000 potential playas were mapped and modeled by the Playa Lakes Joint Venture (2014; PLJV) and Rainwater Basin Joint Venture (2014; RWBJV) based on field observations, compiled data, aerial photography, and models of topographic and soil conditions. Years of research 
on playas have yielded multiple mechanisms and projections for sub-regions of the Great Plains Landscape Conservation Cooperative (GPLCC) area, but a complete, region-wide inventory and assessment has not been completed. To better understand the spatial and temporal distribution of playa wetland inundation, Landsat remote-sensing data (https://landsat.usgs.gov) was processed using a classification algorithm designed to isolate the signature of surface water. Landsat data was acquired to represent the spring seasons of four different years across the GPLCC region.

This project was designed to generate the response variable that will enable formulation and testing of competing models that predict the likelihood of inundation of playa wetlands across the region. Long-term trends in temperature and precipitation are expected to affect the delivery patterns to and retention of water on the surface. This work focused on developing primary data to support regional analysis of these relationships. For this pilot effort, we targeted 4 different years during the spring season, which is frequently wet, for classification across the GPLCC region. These samples were used to develop classification and analytical approaches and to establish the utility of these data acquired from archived, remotely sensed satellite data (Landsat) in characterizing the ephemeral distribution of surface water, in this case inundated playa wetlands, across the Great Plains. Our results are limited because only four years were sampled, as opposed to yearly estimates for each year in the archive (1982-2016). Classification of more years and different seasons would result in greater resolution of inter-annual and interseasonal variations in the distribution of playa wetlands. Subsequent work may benefit from the classification of additional dates using our procedures.

This project was designed to establish classification methods for playa-wetland hydrology and demonstrate the potential value of understanding wetland inundation patterns. Practical limitations restricted our classifications to four years, and we recognize that greater analytical power would be attained from a larger sample set. Therefore, analyses that explicitly connect the response variable (surface water distribution) to environmental drivers are limited until greater temporal resolution can be generated. Based on these results, expansion of the data to additional years and seasons and expansion of the analyses to include the influences of climate, land-cover, and land use could provide a greater understanding of these ecologically important and dynamic habitats.

\section{Methods}

We combined existing data for playa wetland locations with surface water signatures from the Landsat data archive (https://landsat.usgs.gov) to describe the distribution and frequency of inundation across the GPLCC region, which includes portions of South Dakota, Nebraska, Wyoming, Colorado, Kansas, Oklahoma, New Mexico and Texas. Target dates for multiple years were chosen to capture variability in climate patterns; analyses presented here focused on spring-season data (April-June) to provide a consistent comparison among years as well as a temporal window wide enough to provide Landsat data options. To accurately characterize this large area, data with minimal cloud obstructions within the April-June date window were identified for each target year; this often required using several different collection dates to represent the entire region (see distribution of Landsat scenes in figure 1). The spectral radiance of surface water was classified using classification and regression tree models (De'ath and Fabricius, 2000), and the classification was applied across each Landsat scene. These data were compiled to create a spatial dataset, in map form, and a tabular database with water inundation recorded for each location-date combination. Existing data from Playa Lakes Joint Venture (2014) and Rainwater Basin Joint Venture (2014) were used to identify locations of current and historic playa wetlands, respectively. Summaries and analyses of inundation rates were based on coincidence of the Landsat classification of surface water, and previously mapped playa locations. Changes were summarized based on State boundaries within the GPLCC region to provide spatial context and connections to distinct State Fish and Wildlife Agencies, who are important partners in the GPLCC. These summaries also facilitated comparisons with climate patterns described by the Western Regional Climate Center for each sample year.

Landsat scenes were selected to represent spring conditions in four different years by considering a range of sample dates to insure cloud-free perspective across the landscape, and therefore, our results represent the distribution of surface water using a composite of spring collection dates. To account for differences in cloud cover in different places on different dates, spring conditions were represented by data collection between May 4 and June 24 for each target year, 1989, 1996, 2004, and 2008. These years were selected to represent a diverse set of conditions as was indicated by regional climate summaries from regional and state climate centers (High Plains Regional Climate Center, 2014; Oklahoma Climatological Survey, 2014; Office of the Texas State Climatologist, 2014a, 2014b; Water resources data system and Wyoming State Climate Office, 2014; Western Regional Climate Center, 2015). After water classifications were completed, each classified area was independently assessed for accuracy and errors that might have been introduced by data variability created by the sensor or obstruction of reflectance due to clouds and water vapor. Due to the influence of wet soils, surface ponding not related to playas, and water retention structures (small reservoirs and stock ponds), considerable surface water not attributed to playa wetlands is also included in the Landsat classification. After acquisition of a cloud-free composite for the entire area in each year, the Landsat data was processed using a semi-automated process to classify the signature of surface water in each Landsat scene. 


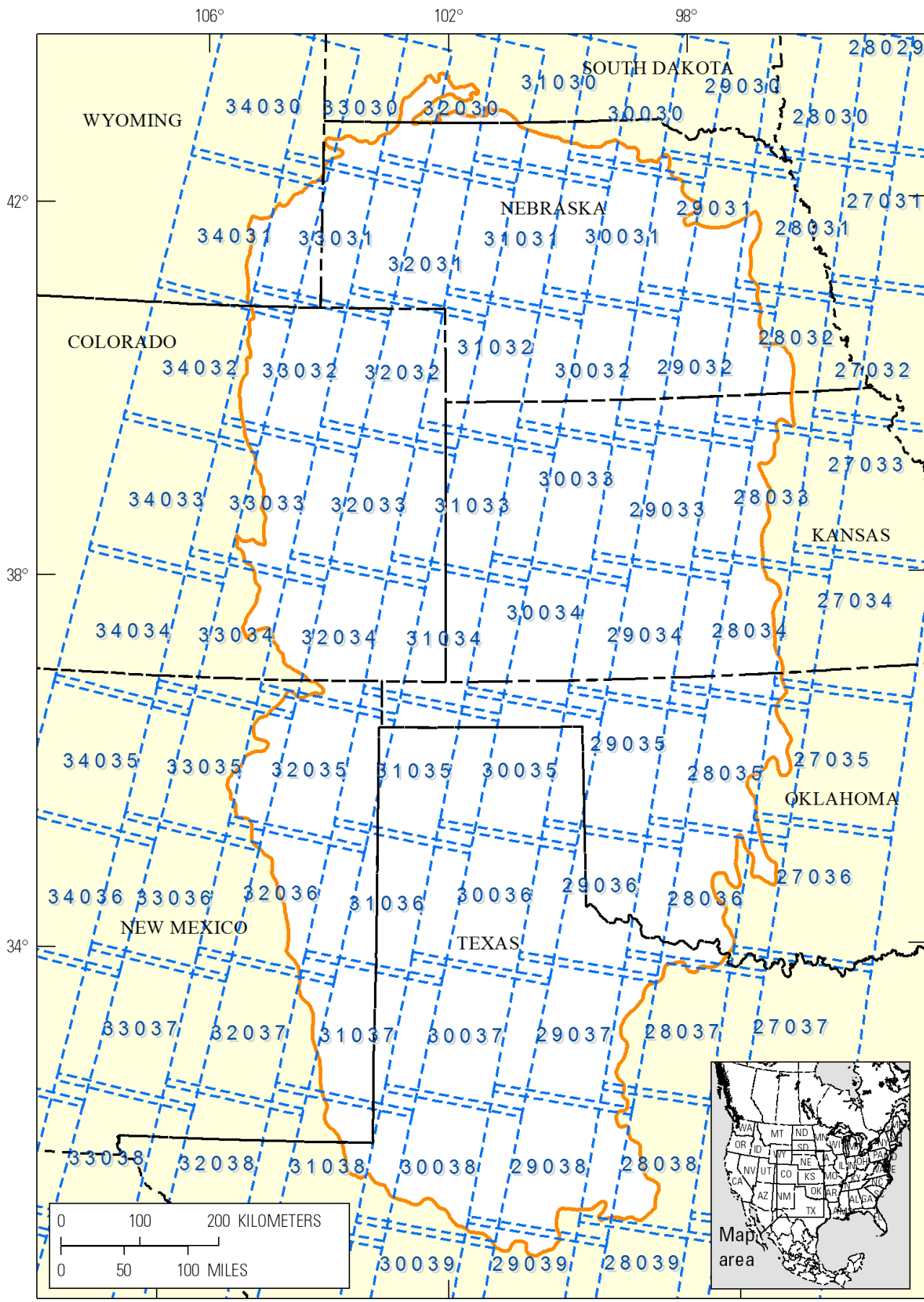

\section{EXPLANATION}

$I^{---}$I Landsat scene

Great Plains

Landscape

Conservation

Cooperative

boundary

Figure 1. Distribution of Landsat scenes (Landsat path-row footprints) used to observe surface water across the Great Plains Landscape Conservation Cooperative. The Landsat program includes a series of sensors which pass over each location on the earth's surface at scheduled intervals (16 days). Consistent tracking by the satellites creates a series of 185-kilometer (115-mile) paths, which are divided into rows by packaging the path data into square regions known as scenes. The data-collection and archive format enables comparison of single scenes, identified by path and row, or mosaics of scenes stitched together. 
The approach described here links attributes of these several datasets using the previously mapped playa-wetland locations as the denominator in percent inundation estimates (available compared to potential wetland area), and using the Landsat classifications to describe the inundated area. Use of the existing datasets as the framework for analyses made these results comparable to existing information and facilitated calculations that account for playa wetlands that were never inundated during our sample periods. Wetland locations in the current PLJV data are regarded as "probable" because some locations in the data are confirmed playa wetlands and other locations have evidence consistent with playa wetland occurrence but have not been confirmed due to infrequent and variable inundation over time and a large, and sometimes inaccessible, landscape. Wetland locations within the Rainwater Basin region were mapped using observations from multiple years (2004-2009) and historic soil and wetland surveys; although RWBJV does not label these wetlands as "probable," uncertainty about the specific hydrology of each wetland makes this label appropriate for these data. A summary of the comparisons of wetlands holding water compared to dry playa wetlands based on the compiled playa data is provided in this report.

Scenes were classified using a computing process developed to (1) align pixels for the same area acquired on different dates, correcting for spatial wobble inherent in multiple-date processing and (2) identify scene- and date-specific water signatures that inform multi-date comparisons. These corrections are important for providing a consistent and accurate spatial assessment, which is critical for change analyses.

Surface reflectance corrections and cloud masks were developed for each date, as necessitated by variability among collection dates and sensor conditions. For areas where cloud cover was an issue, multiple scenes were selected to optimize the portions of the scene that were cloud-free. The processing flow developed here enabled data extraction adventitiously in scenes not obstructed by clouds during the temporal target window, searching scenes (Landsat path-row locations) for cloud-free views between April 1 and June 30 in each target year. This resulted in some playa wetlands having more than 4 observations in the dataset, which we reconciled during analyses by aggregating observations from the same year. Through a combination of processing steps in ArcGIS (Environmental Systems Research Institute [Esri] version 10.3.1), Python (Python Software Foundation, open source, https://www.python.org/psf/), Visual Basic ([VBA] version 6, Microsoft Corporation), and Excel (spreadsheet software, Microsoft Corporation), the following steps were used to construct annual classifications:

1. Classification and regression tree (CART) models were developed to identify wet cells based on spectral signatures from 220 Landsat scenes representing 1-4 dates between May 4 and June 24 for each target year $(1989,1996,2004,2008)$. The minimum mapping unit (MMU) was 616 square meters $\left(\mathrm{m}^{2}\right)$, which is 68 percent of a $30 \times 30$ meter $(\mathrm{m})$ pixel. Tests determined that water bodies occupying 68 percent or more of a $30 \times 30 \mathrm{~m}$ pixel $\left(900 \mathrm{~m}^{2}\right)$ are detected by the CART algorithm. This is reflected in the minimum polygon size in classification products.

2. Cloud mask shapefiles were created for areas with clouds, shadows, or other areas with consistent misclassification, such as burn scars, and these records were used to edit classifications of Landsat pixels. Wet polygons affected by clouds or other obstructions were revised by manual interpretation of each scene to accurately identify and separate these anomalous data. This was an important quality control step.

3. Wetland polygon layers compiled from data for multiple dates were intersected with cloud masks, assigned values for "clouds" and "non-clouds" in the attribute table, and used to populate a unique water-signature field in the attribute table. All layers were merged into a single shapefile for each year.

4. Wetland features that did not intersect clouds were identified and geometry was calculated for each feature. Then, the final playa data layer was created using data-management tools to dissolve merged boundaries and assign multipart features. A new unique identifier field based on object ID was defined.

5. All data were aggregated into a file geodatabase consisting of one dissolved zone dataset and four merged wetland datasets.

6. A combination of data management and analysis tools were used to tabulate a summary of the total area (in square meters) for all wetland polygons from each year that intersect each polygon. All Landsat attribute fields and area estimates for all features were retained using unique identifiers. The final table was joined with spatial data using the unique identifier field.

7. The final product is a file geodatabase feature class (Manier and Rover, 2018). An example of a small portion of the landscape with wet and dry playas is provided in figure 2 . 


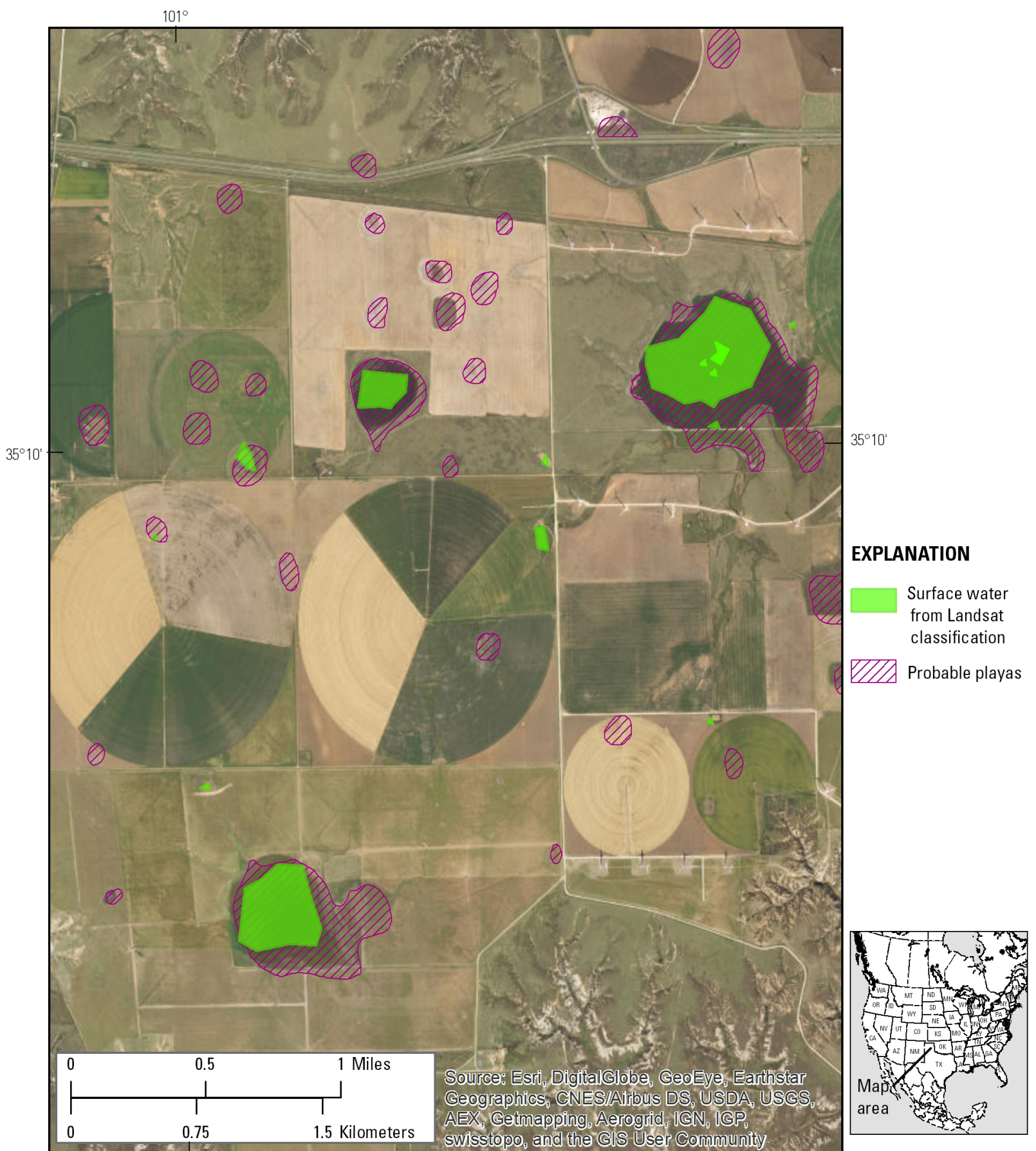

$101^{\circ}$

Figure 2. Close-up view of north Texas, east of Amarillo, showing surface water from Landsat classification (green; based on the four classification years) and probable playas (purple). This scene includes 3 large playas that were inundated at least once during the assessment intervals, 2 playas that were wet but below capacity during the assessment intervals, several small playas that were not wet during the assessment intervals, a small rectangular pond, and several small wet polygons that are likely superfluous information related to ponding or soil saturation during one assessment interval. Locations of probable playas from Playa Lakes Joint Venture (2014) and Rainwater Basin Joint Venture (2014). Base map is the intellectual property of Esri and is used herein under license. Copyright (c) 2017 Esri and its licensors. All rights reserved. 
The resulting dataset was analyzed using pairwise analysis of variance (ANOVA) for presence of water (presence or absence at any level of inundation) and percent of the wetland footprint inundated with water. Comparisons among States and between years were used to identify spatial and temporal variability, respectively, in inundation rates. Generalized linear models (GLM) were used to compare inundation rates over time within each state and among states in each year. Importantly, due to limitations of the spectral classification process, water bodies smaller than $616 \mathrm{~m}^{2}$, or portions of water bodies smaller than $616 \mathrm{~m}^{2}$ within Landsat pixels $\left(900-\mathrm{m}^{2}\right.$ cell), are not included in the classified results.

\section{Results}

Our assessment indicates that only 20.5 percent of all confirmed and potential playa wetlands (hereafter, "potential playas") held water during at least one of the four spring seasons in our assessment (1989, 1996, 2004, and 2008; table 1). These inundation events covered only 21.0 percent of the previously delineated playa areas. These values are estimated across all playas within the GPLCC region; thus, local rates for different areas, such as States, within the region may display greater or lesser inundation percentages than the regional average. Within the years sampled, the number of playas inundated annually was considerably less than the 4-year mean, ranging from 4.16 percent (1996) to 12.59 percent (2008), indicating that annual habitat availability from these wetlands is considerably less than the multi-year average. The number and area of inundated playas were significantly different among years (ANOVA, $\operatorname{Pr}(>F)^{1}$ was $<0.001$ in all cases). Based on these data (table 1), 2008 was a wet year for playas, because the inundation percentages in 1989, 1996, and 2004 were one-third to one-half the levels recorded in 2008 (4.91, 4.16, and 5.98 percent compared to 12.59 percent, respectively).

State-level inter-annual summaries provided better resolution of variability in playa inundation within each state in the Landscape Conservation Cooperative area. Differences in the number of playas holding water between years were significant across the entire region, and within each state $\left(\operatorname{Pr}(|z|)^{2}<0.001\right.$ in all cases; table 2). The 4-year range provides additional insight into variability in habitat availability through time (table 2). The percent of mapped playa areas inundated by water (percent inundation) is also highly variable between states and years, and values indicated that only a small percent of the available area holds water each spring (table 3). Curiously, regional precipitation indices for these periods (January-June 1989, 1994, 2004, 2008) are consistent with this playa-based assessment only in their variability between years and locations (fig. 3, table 4), and although seasonal precipitation is known to affect playas, the 6-month summaries offer little explanatory value alone. Nonetheless, because of the important relation between precipitation trends and inundation of playas, regional indices were considered during interpretation of the results.

Table 1. Summary of Landsat-based classifications of the occurrence of surface water within probable playas across the Great Plains Landscape Conservation Cooperative. All count- and area-based estimates were significantly different between years and from the inter-annual mean (analysis of variance pairwise comparisons, $\operatorname{Pr}(>\mathrm{F})<0.001)$. Mapped distributions are provided in figures 5-12. Locations of probable playas from Playa Lakes Joint Venture (2014) and Rainwater Basin Joint Venture (2014).

$[\operatorname{Pr}(>F)$ is statistical notation for the probability that the ratio of between-sample variance to within-sample variance exceeds the critical value $\mathrm{F}$ by chance alone when the null hypothesis was true, in this case 1 in 1000 . Therefore, there is a very small probability that the null hypothesis is true and we conclude that the samples are significantly different. --, no data]

\begin{tabular}{lccccccc}
\hline \multirow{2}{*}{ Statistic } & \multicolumn{3}{c}{ Year } & \multicolumn{2}{c}{$\begin{array}{c}\text { Annual } \\
\text { mean }\end{array}$} & $\begin{array}{c}\text { 4-year } \\
\text { rate }\end{array}$ \\
\cline { 2 - 6 } & $\mathbf{1 9 8 9}$ & $\mathbf{1 9 9 6}$ & $\mathbf{2 0 0 4}$ & $\mathbf{2 0 0 8}$ & & \\
Percent of playas that held any water (count-based) & 4.91 & 4.16 & 5.98 & 12.59 & & 6.91 & 20.5 \\
Mean percent of area inundated & 4.95 & 3.58 & 4.67 & 10.99 & 6.05 & 21.02 \\
Maximum percent of area inundated & 6.37 & 5.25 & 5.11 & 13.05 & 7.45 & -- \\
Minimum (non-zero) percent of area inundated & 4.2 & 2.56 & 4.22 & 9.65 & 5.16 & -- \\
\hline
\end{tabular}

${ }^{1} \operatorname{Pr}(>F)$ is statistical notation for the probability that the ratio of between-sample variance to within-sample variance exceeds the critical value $F$ by chance alone when the null hypothesis was true, in this case 1 in 1000 . Therefore, there is a very small probability that the null hypothesis is true and we conclude that the samples are significantly different.

${ }^{2} \operatorname{Pr}(>|z|)$ is statistical notation for the probability that the ratio of between-sample variance to within-sample variance exceeds the critical value $z$ by chance alone when the null hypothesis was true, in this case 1 in 1000 . Therefore, there is a very small probability that the null hypothesis is true and we conclude that the samples are significantly different. 
Table 2. Summary of playas that held any amount of water during the evaluation years, based on the count of probable playa locations with water signatures in Landsat classifications. Calculations were constrained to the 4 years included in this study. Differences between states and years are significant in all cases (generalized linear models, $\operatorname{Pr}(>|z|)<0.001)$. Locations of probable playas from Playa Lakes Joint Venture (2014) and Rainwater Basin Joint Venture (2014).

$[\operatorname{Pr}(>|z|)$ is statistical notation for the probability that the ratio of between-sample variance to within-sample variance exceeds the critical value $z$ by chance alone when the null hypothesis was true, in this case 1 in 1000. Therefore, there is a very small probability that the null hypothesis is true and we conclude that the samples are significantly different]

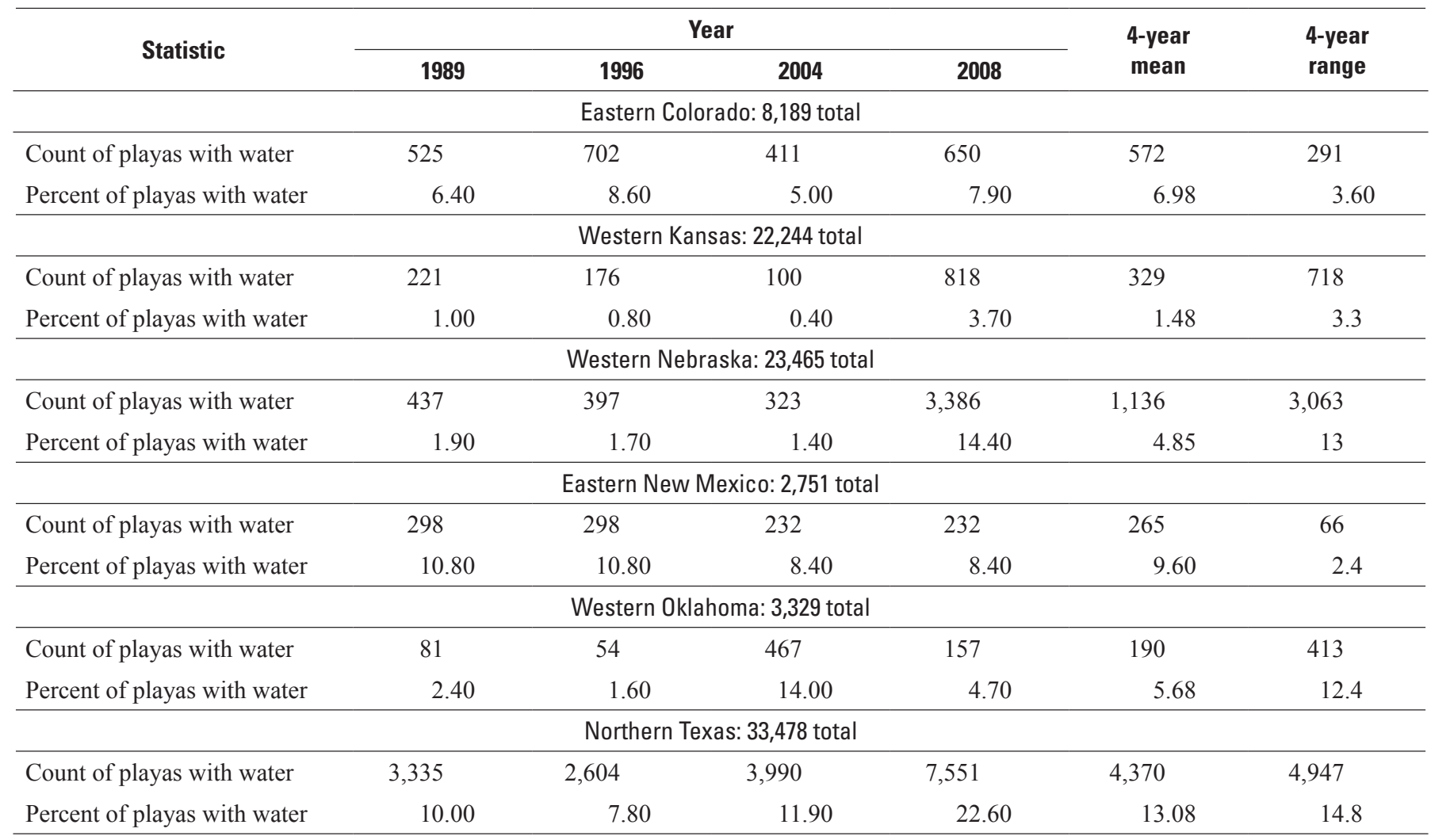

Table 3. Percent of area defined in the probable playas datasets (Playa Lakes Joint Venture, 2014; Rainwater Basin Joint Venture, 2014) covered by water according to Landsat surface water classification for each state and year. Differences in percent inundated area between states are significant in all cases (generalized linear models, $\operatorname{Pr}(>|z|)$ is $<0.001)$. Mapped distributions are provided in figures $5-9$.

$[\operatorname{Pr}(>|z|)$ is statistical notation for the probability that the ratio of between-sample variance to withinsample variance exceeds the critical value $z$ by chance alone when the null hypothesis was true, in this case 1 in 1000 . Therefore, there is a very small probability that the null hypothesis is true and we conclude that the samples are significantly different]

\begin{tabular}{lcccc}
\hline \multirow{2}{*}{ Geographic area } & \multicolumn{4}{c}{ Percent inundation, by year } \\
\cline { 2 - 5 } & $\mathbf{1 9 8 9}$ & $\mathbf{1 9 9 6}$ & $\mathbf{2 0 0 4}$ & $\mathbf{2 0 0 8}$ \\
\hline Eastern Colorado & 7.92 & 10.62 & 6.31 & 10.6 \\
Western Kansas & 0.16 & 0.2 & 0.11 & 1.16 \\
Western Nebraska & 9.04 & 14.01 & 1.17 & 31.33 \\
Eastern New Mexico & 13.13 & 11.04 & 9.28 & 7.88 \\
Western Oklahoma & 3.98 & 0.64 & 10.96 & 2.59 \\
Northern Texas & 4.47 & 2.19 & 4.88 & 12.27 \\
\hline
\end{tabular}


Table 4. Assessment of precipitation patterns using the Standardized Precipitation Index (SPI; McKee and others, 1993) for climate divisions (geographic areas) within the boundary of the Great Plains Landscape Conservation Cooperative (GPLCC) (compare to table 3 for qualitative assessment of precipitation history and inundation). Table entries provide a qualitative summary of the SPI conditions for the climate divisions within the GPLCC in each state.

$[+3, \mathrm{SPI}>2$, extremely wet; $+2, \mathrm{SPI}=1.5-1.99$, very wet; $+1, \mathrm{SPI}=1.0-1.5$, moderately wet; NN, SPI $=-0.99-0.99$, near normal; -1 , SPI $=-1.0--1.5$, moderately dry; -2 , SPI $=-1.5--2.0$, very dry; -3 , SPI $<-2.0$, extremely dry. Multiple entries indicate variability within the geographic area that year (range of reported values provided). For example, "NN, (1@+1)" indicates near normal conditions in most divisions, but one climate division was different than others in the geographic area; in this example, SPI was elevated to +1]

\begin{tabular}{lcccc}
\hline \multirow{2}{*}{ Geographic area } & \multicolumn{4}{c}{ Broad-scale precipitation patterns, by year } \\
\cline { 2 - 5 } & $\mathbf{1 9 8 9}$ & $\mathbf{1 9 9 6}$ & $\mathbf{2 0 0 4}$ & $\mathbf{2 0 0 8}$ \\
\hline Eastern Colorado & $\mathrm{NN}$ & $\mathrm{NN}$ & $\mathrm{NN}$ & -2 \\
Western Kansas & $\mathrm{NN}, 1 @+1$ & $\mathrm{NN}, 1 @-1$ & $\mathrm{NN}$ & $\mathrm{NN}, 1 @-1$ \\
Western Nebraska & $\mathrm{NN},-1,-2$ & $\mathrm{NN}$ & $\mathrm{NN}, 1 @-1$ & $\mathrm{NN}, 1 @+1$ \\
Eastern New Mexico & $\mathrm{NN}$ & $\mathrm{NN}$ & $+1,+2$ & -1 \\
Western Oklahoma & +2 & -1 & $\mathrm{NN}$ & -2 \\
Northern Texas & $\mathrm{NN}$ & -2 & +1 & $\mathrm{NN}$ \\
Southwest South Dakota & $-1,-2$ & $\mathrm{NN}$ & $\mathrm{NN},-1,-2$ & $\mathrm{NN},+1,+2$ \\
\hline
\end{tabular}




\section{A}

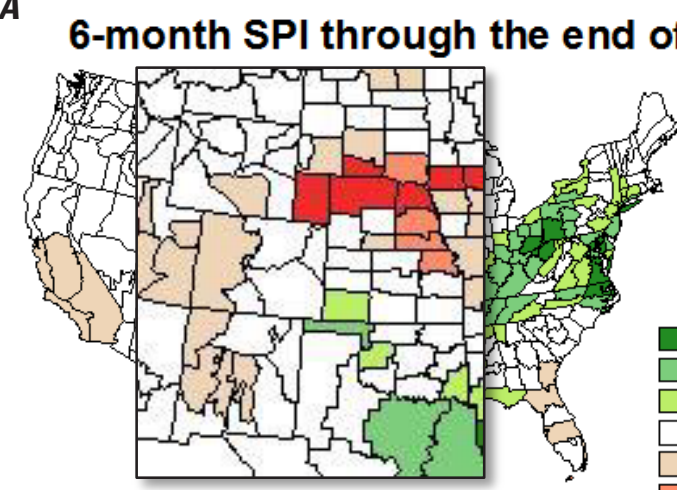

Copyright $\odot 2012$ National Droug ht Mitigation Center

\section{$B$}

\section{6-month SPI through the end of June 1996}

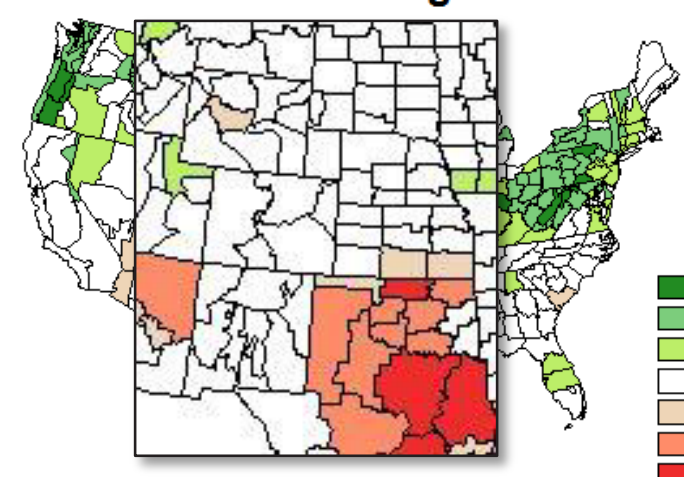

Copyright @ 2011 National Drought Mitigation Center

C

\section{6-month SPI through the end of June 2004}

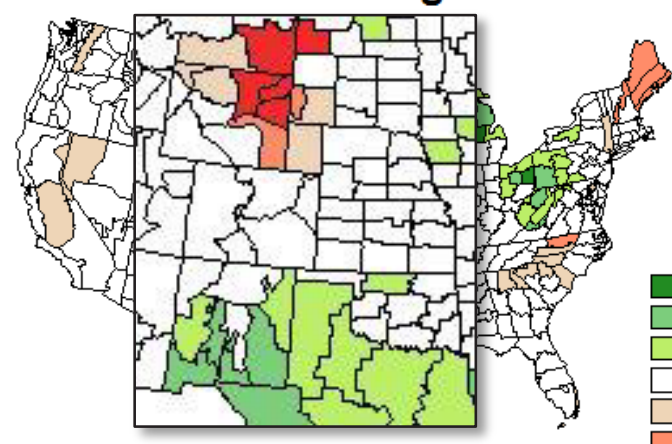

Copyright @ 2011 National Drought Mitigation Center

D

\section{6-month SPI through the end of June 2008}

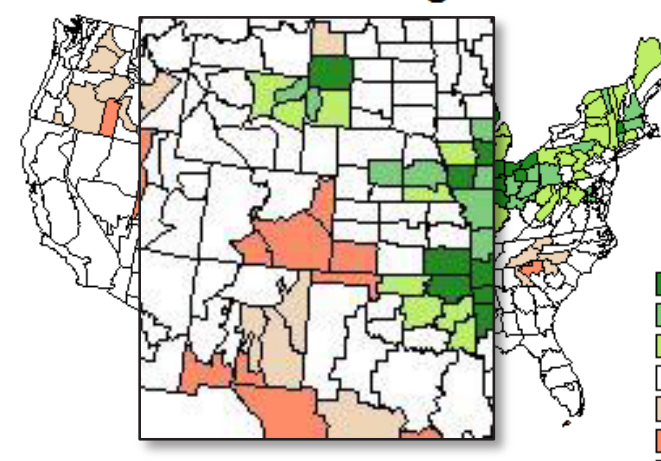

Copyright (c) 2011 National Drought Mitigation Center
+2.0 and a bove (Extremely Wet) +1.50 to +1.99 (Very Wet) $+1.010+1.49$ (Moderately Wet) -0.99 to +0.99 (Near Normal) -1.00 to -1.49 (Moderately Dry) -1.50 to -1.99 (Very Dry) -2.0 and below (Extremely Dry)
+2.0 and above (Extremely Wet) +1.50 to +1.99 (Very Wet) $+1.010+1.49$ (Moderately Wet) -0.99 to +0.99 (Near Normal) -1.00 to -1.49 (Moderately Dry) -1.50 to -1.99 (Very Dry) -2.0 and below (Extremely Dry)
2.0 and a bove (Extremely Wet) +1.50 to +1.99 (Very Wet) $+1.010+1.49$ (Moderately Wet) -0.99 to +0.99 (Near Normal) -1.00 to -1.49 (Moderately Dry) -1.50 to -1.99 (Very Dry) -2.0 and below (Extremely Dry)
Figure 3. National Drought Mitigation Center summaries of climate-induced moisture indicating drought conditions, for 6-month periods, January-June, for 4 different years. These maps provide an indication of regional trends in precipitation, which partially determines the likelihood of playa inundation. SPI is the Standardized Precipitation Index, which was designed as a drought indicator. A, 1989. B, 1996. C, 2004. D, 2008. [Data and figures from National Drought Mitigation Center used by permission.] 
According to our compiled probable playa data, there are 93,456 probable playas located across the GPLCC region, with an acreage of more than 690,500 acres (279,450 hectares [ha]). However, even with a mean size of 123 acres (49 ha), and a median of 41 acres (17 ha), a highly skewed distribution, with smaller wetlands being predominant, is clearly present (fig. 4). These statistics have important implications for available habitat distribution. Examples of the spatial distribution of potential and inundated playa wetlands across the region, and within focal areas, help to describe the highly variable nature of the occurrence of surface water in these important habitats (figs. 5-12).

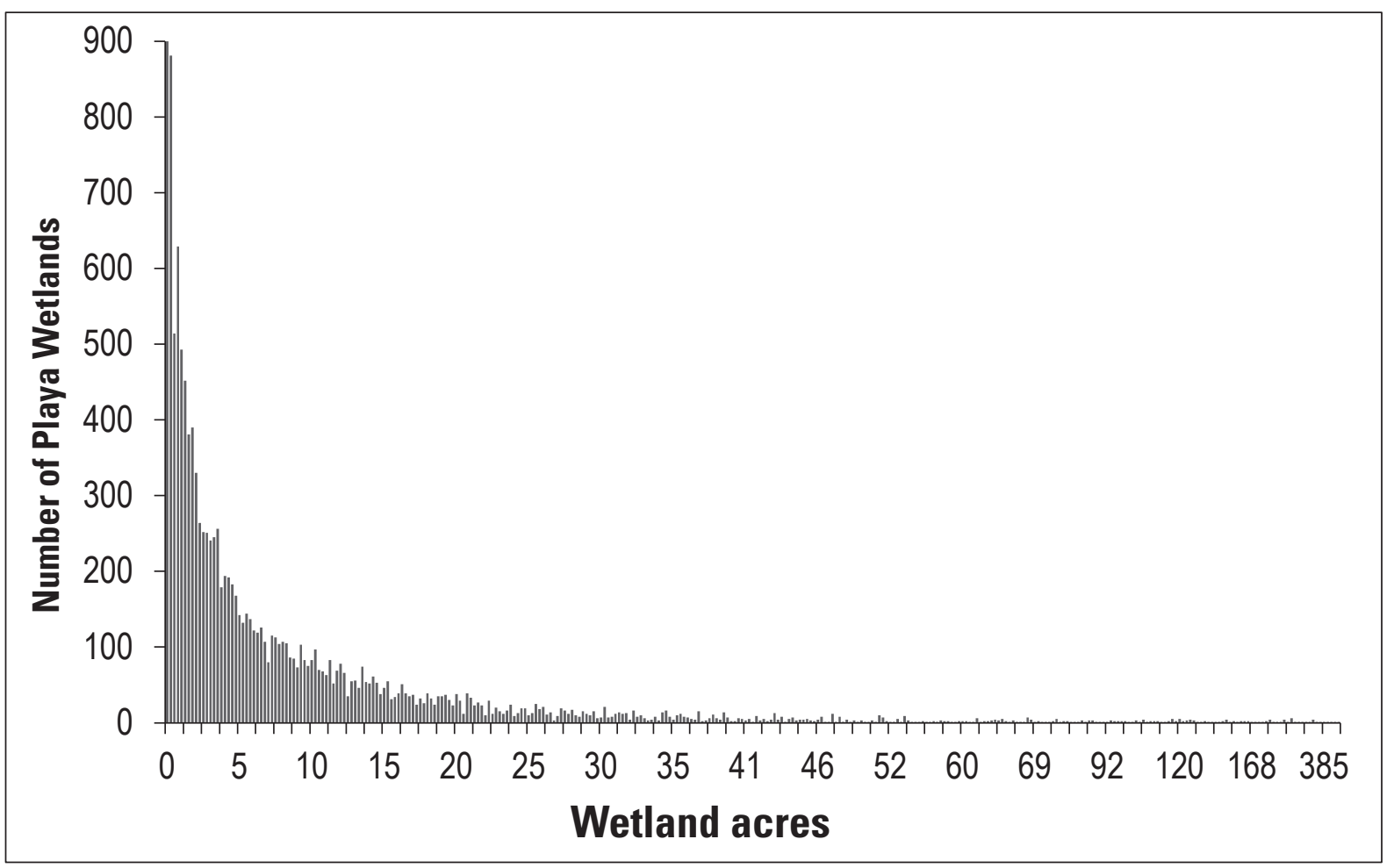

Figure 4. Frequency-distribution plot of playa surface-area estimates for 1989, 1996, 2004, and 2008. To facilitate display, dry playas (zero area) and the smallest size class ( 0 acres, 0.25 acre) have been removed $(74,299$ and 5,745 playas were in those classes, respectively). This distribution demonstrates the importance of conservation of many different sizes of playa across the Great Plains Landscape Conservation Cooperative, including small playas of less than 1 acre, to support habitat availability and aquifer recharge. 


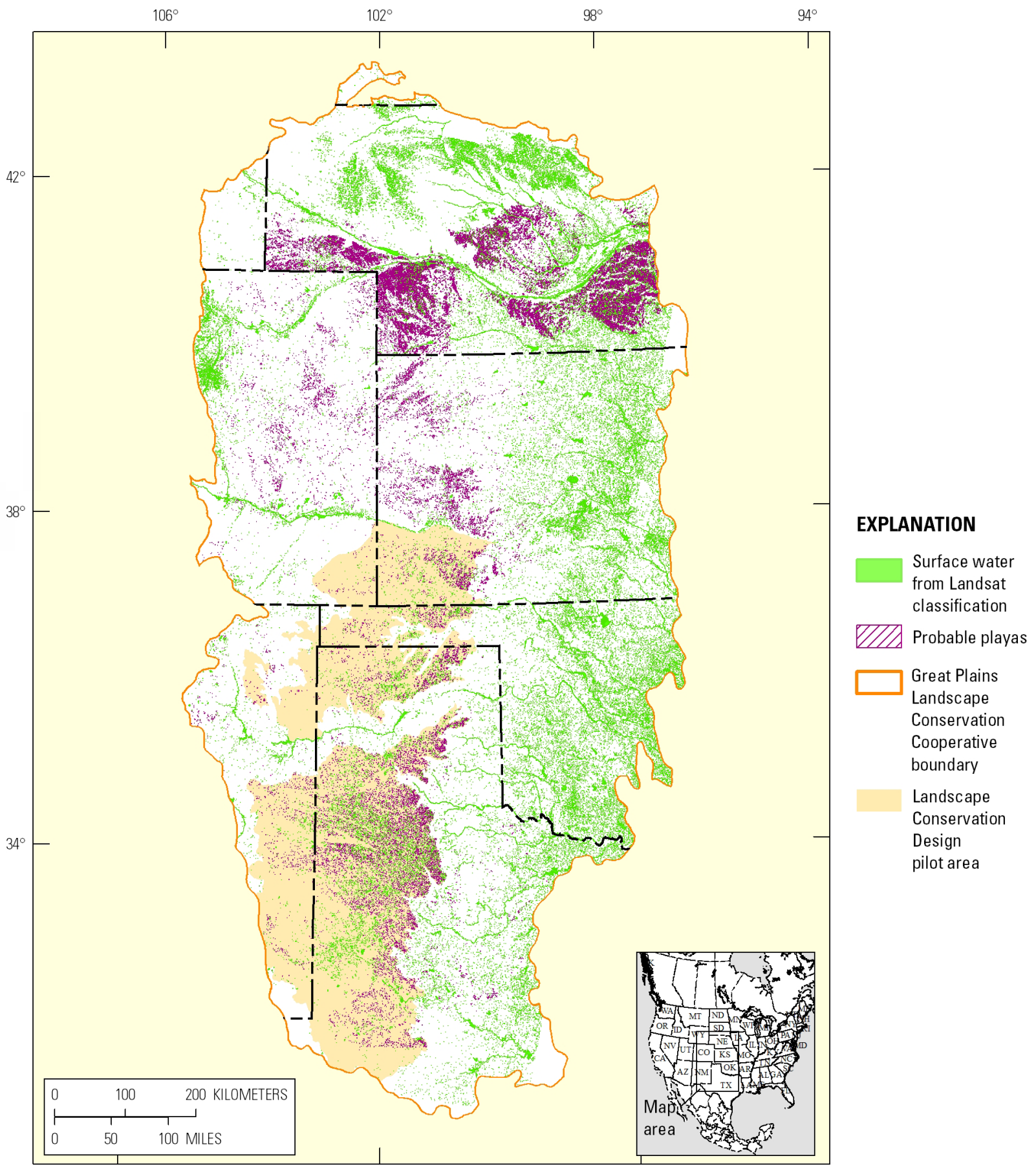

Figure 5. Map showing the distribution of surface water and probable playas in the Great Plains Landscape Conservation Cooperative (GPLCC) in the springs of 1989, 1996, 2004, and 2008. Probable playas that did not hold water during the spring of the sample years (purple) and surface water from Landsat (green; any amount of inundation during the spring of the sample years) are shown. The GPLCC Landscape Conservation Design pilot area is provided for reference (tan). Probable-playa areas from Playa Lakes Joint Venture (2014) and Rainwater Basin Joint Venture (2014). 


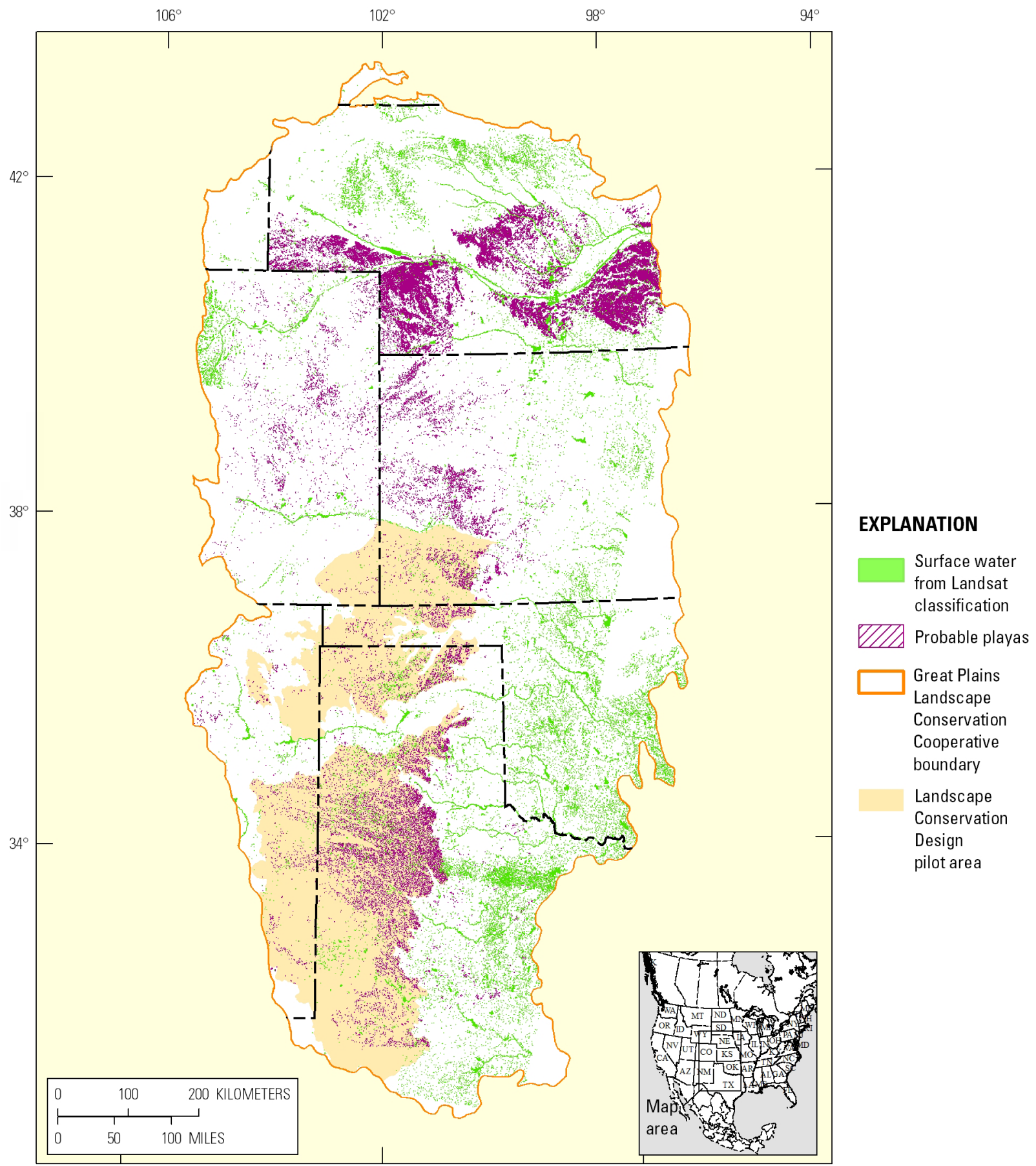

Figure 6. Map showing the distribution of surface water and probable playas in the Great Plains Landscape Conservation Cooperative (GPLCC) in the spring of 1989. Probable playas that did not hold water during the spring (purple) and surface water from Landsat (green) are shown. This classified wetness surface depicts wetlands and open water without being limited to known wetlands and water features. The GPLCC Landscape Conservation Design pilot area is provided for reference (tan). Probable-playa areas from Playa Lakes Joint Venture (2014) and Rainwater Basin Joint Venture (2014). 


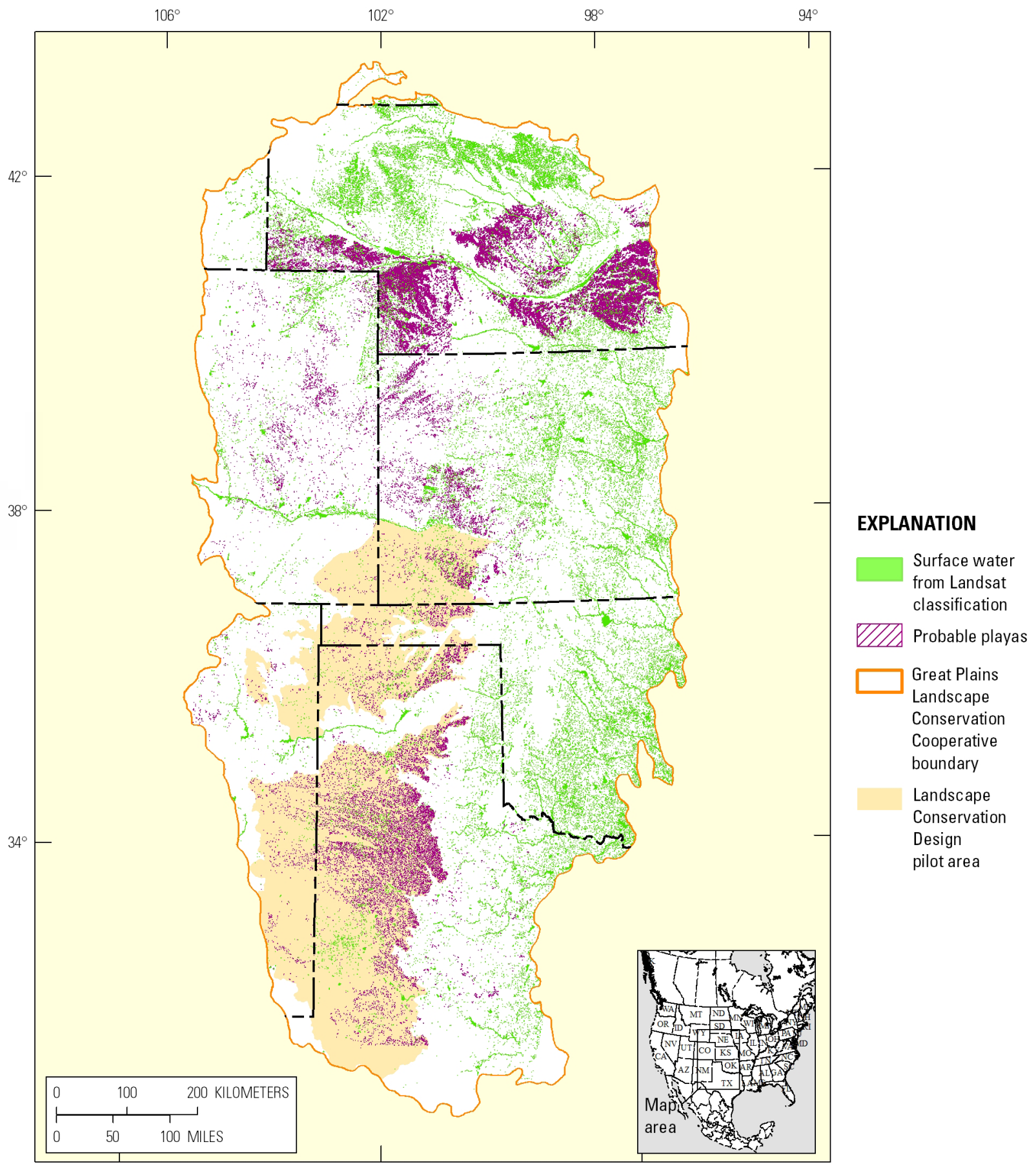

Figure 7. Map showing the distribution of surface water and probable playas in the Great Plains Landscape Conservation Cooperative (GPLCC) in the spring of 1996. Probable playas that did not hold water during the spring (purple) and surface water from Landsat (green) are shown. This classified wetness surface depicts wetlands and open water without being limited to known wetlands and water features. The GPLCC Landscape Conservation Design pilot area is provided for reference (tan). Probable-playa areas from Playa Lakes Joint Venture (2014) and Rainwater Basin Joint Venture (2014). 


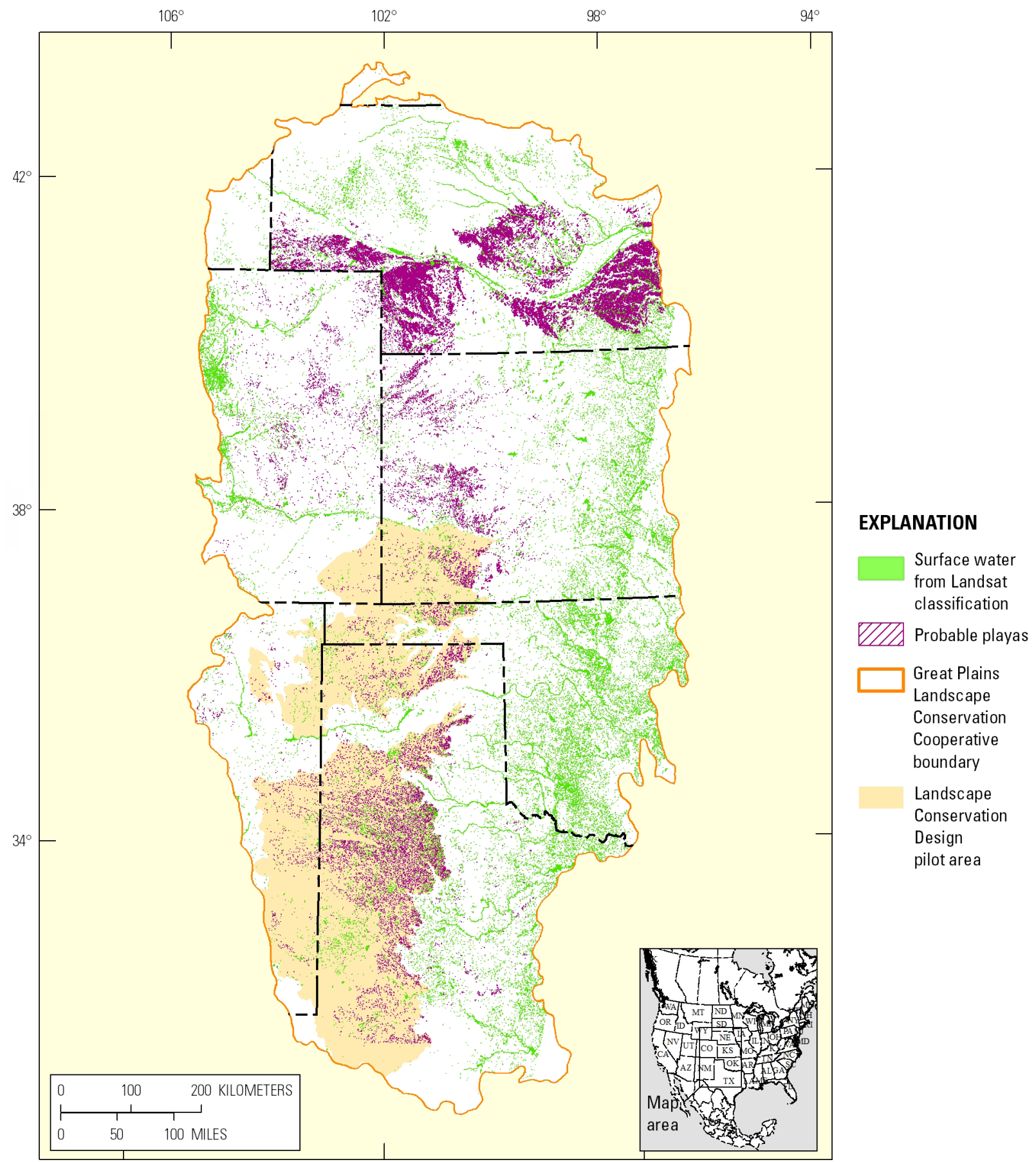

Figure 8. Map showing the distribution of surface water and probable playas in the Great Plains Landscape Conservation Cooperative (GPLCC) in the spring of 2004. Probable playas that did not hold water during the spring (purple) and surface water from Landsat (green) are shown. This classified wetness surface depicts wetlands and open water without being limited to known wetlands and water features. The GPLCC Landscape Conservation Design pilot area is provided for reference $(\tan )$. Probable-playa areas from Playa Lakes Joint Venture (2014) and Rainwater Basin Joint Venture (2014). 


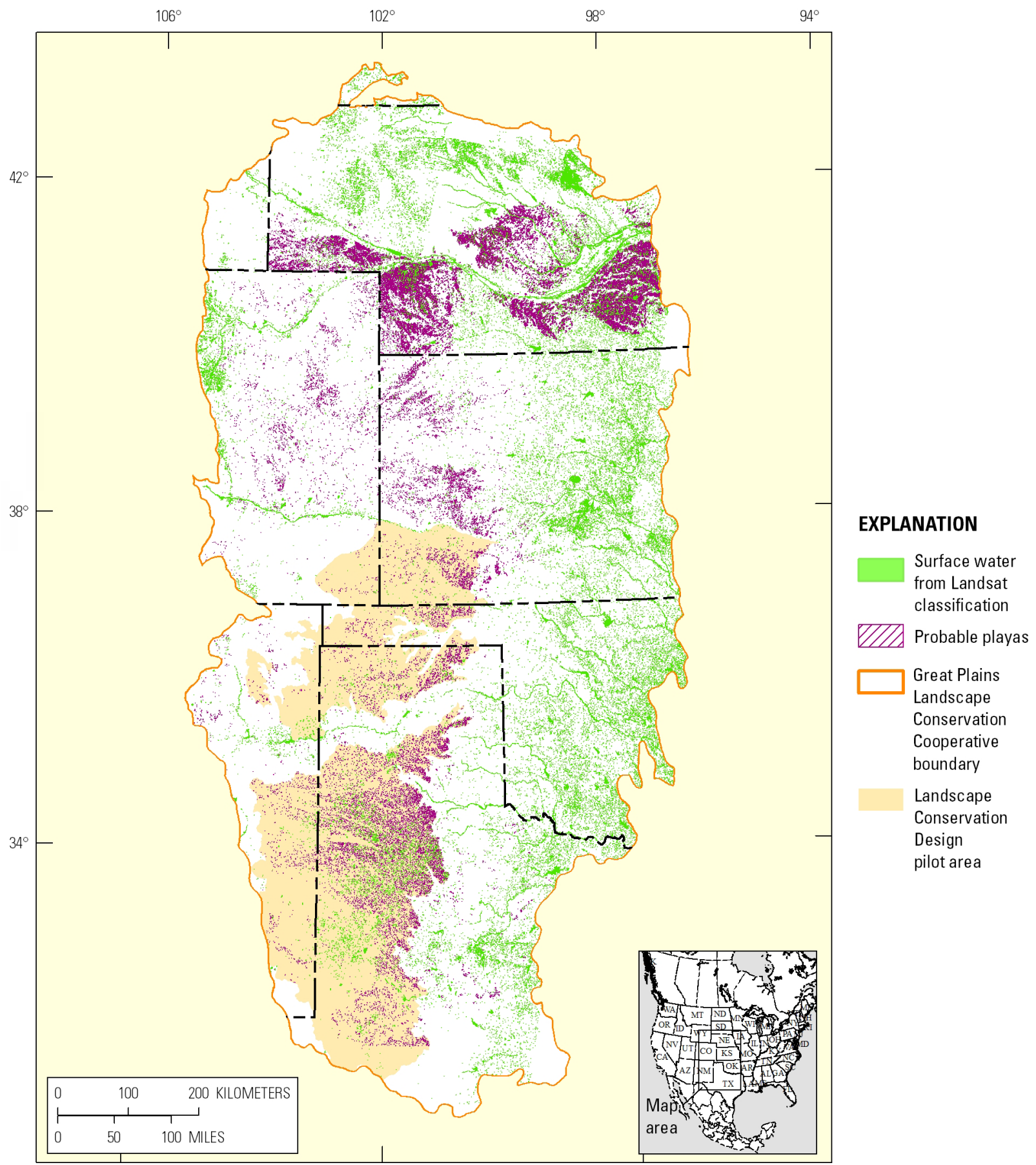

Figure 9. Map showing the distribution of surface water and probable playas in the Great Plains Landscape Conservation Cooperative (GPLCC) in the spring of 2008. Probable playas that did not hold water during the spring (purple) and surface water from Landsat (green) are shown. This classified wetness surface depicts wetlands and open water without being limited to known wetlands and water features. The GPLCC Landscape Conservation Design pilot area is provided for reference (tan). Probable-playa areas from Playa Lakes Joint Venture (2014) and Rainwater Basin Joint Venture (2014). 


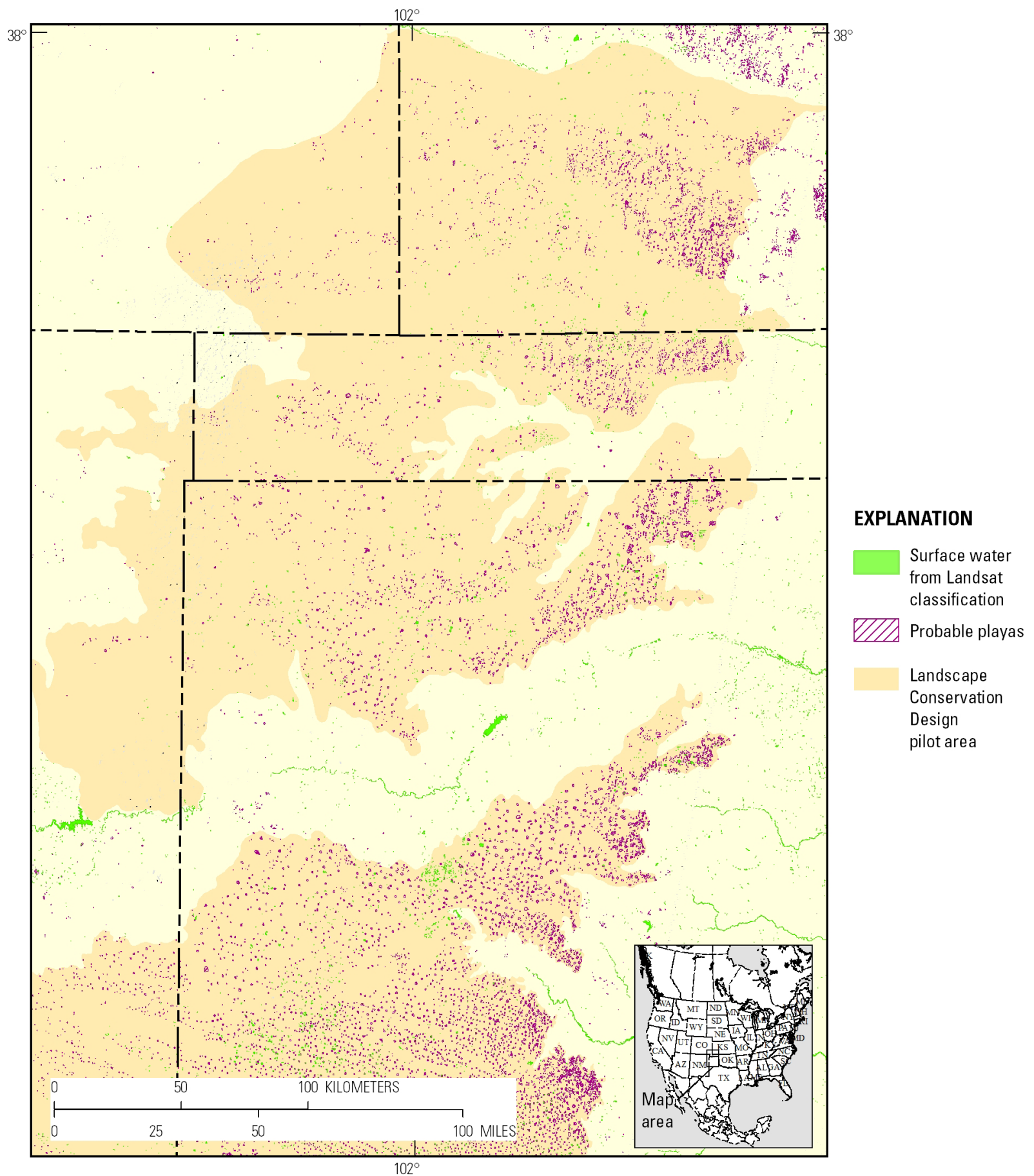

Figure 10. Map showing an enlarged view of the distribution of surface water and probable playas in part of Texas, within the Great Plains Landscape Conservation Cooperative (GPLCC) in the spring of 2008. Probable playas (purple) and surface water from Landsat (green) are shown. This figure demonstrates the complex pattern of habitat availability created by intermittent inundation with water across the GPLCC Landscape Conservation Design pilot area (tan). Probable-playa areas from Playa Lakes Joint Venture (2014). 


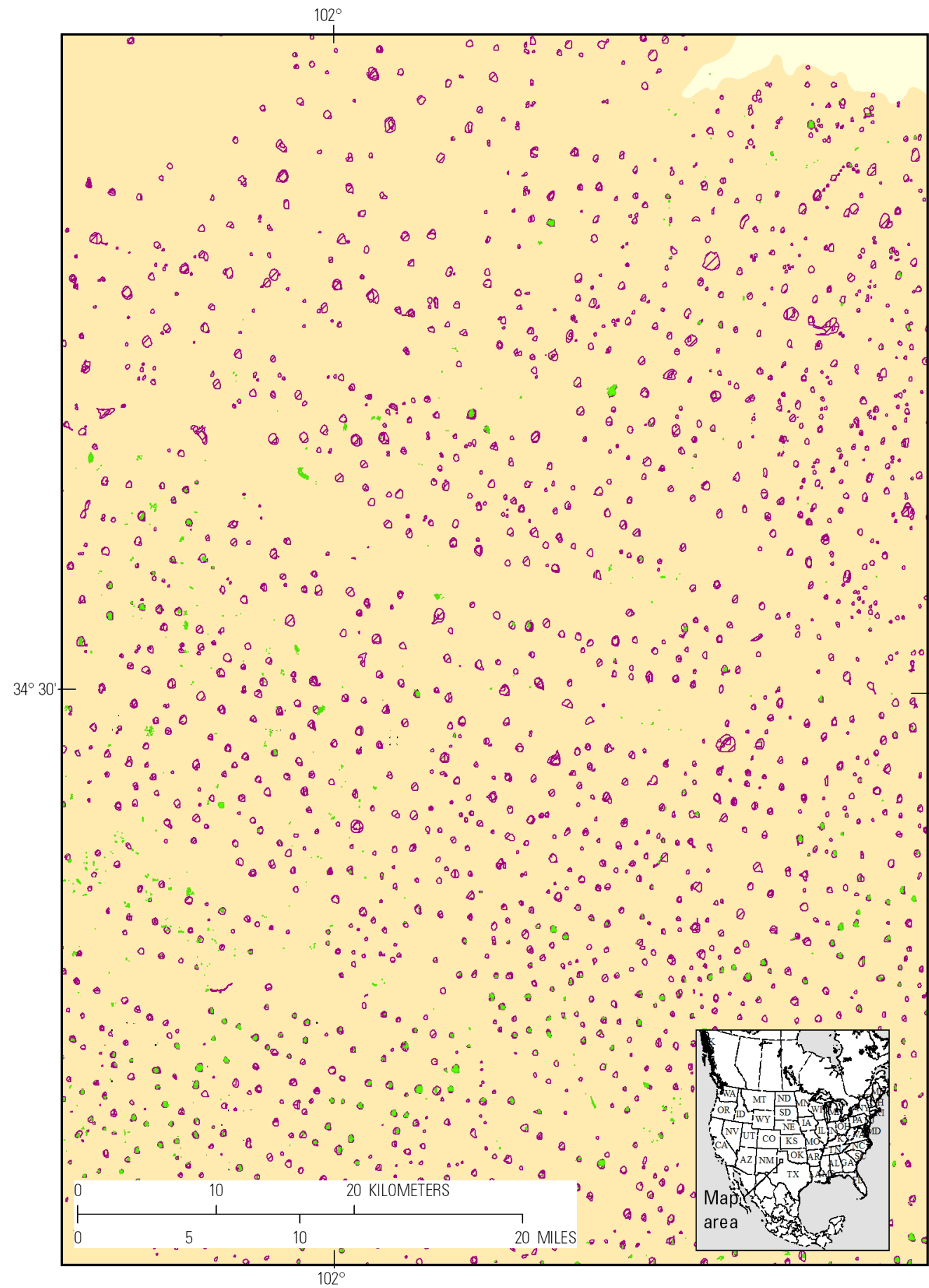

\section{EXPLANATION}

Surface water from Landsat classification

Probable playas

Landscape Conservation Design pilot area

Figure 11. Map showing a view even more enlarged than that of figure 10, showing the distribution of surface water and probable playas in the Great Plains Landscape Conservation Cooperative (GPLCC) in the spring of 2008. Probable playas (purple) and surface water from Landsat (green) are shown. This figure demonstrates the complex pattern of habitat availability created by intermittent inundation with water in this part of northern Texas within the GPLCC Landscape Conservation Design pilot area (tan). Probable playa areas from Playa Lakes Joint Venture (2014). 


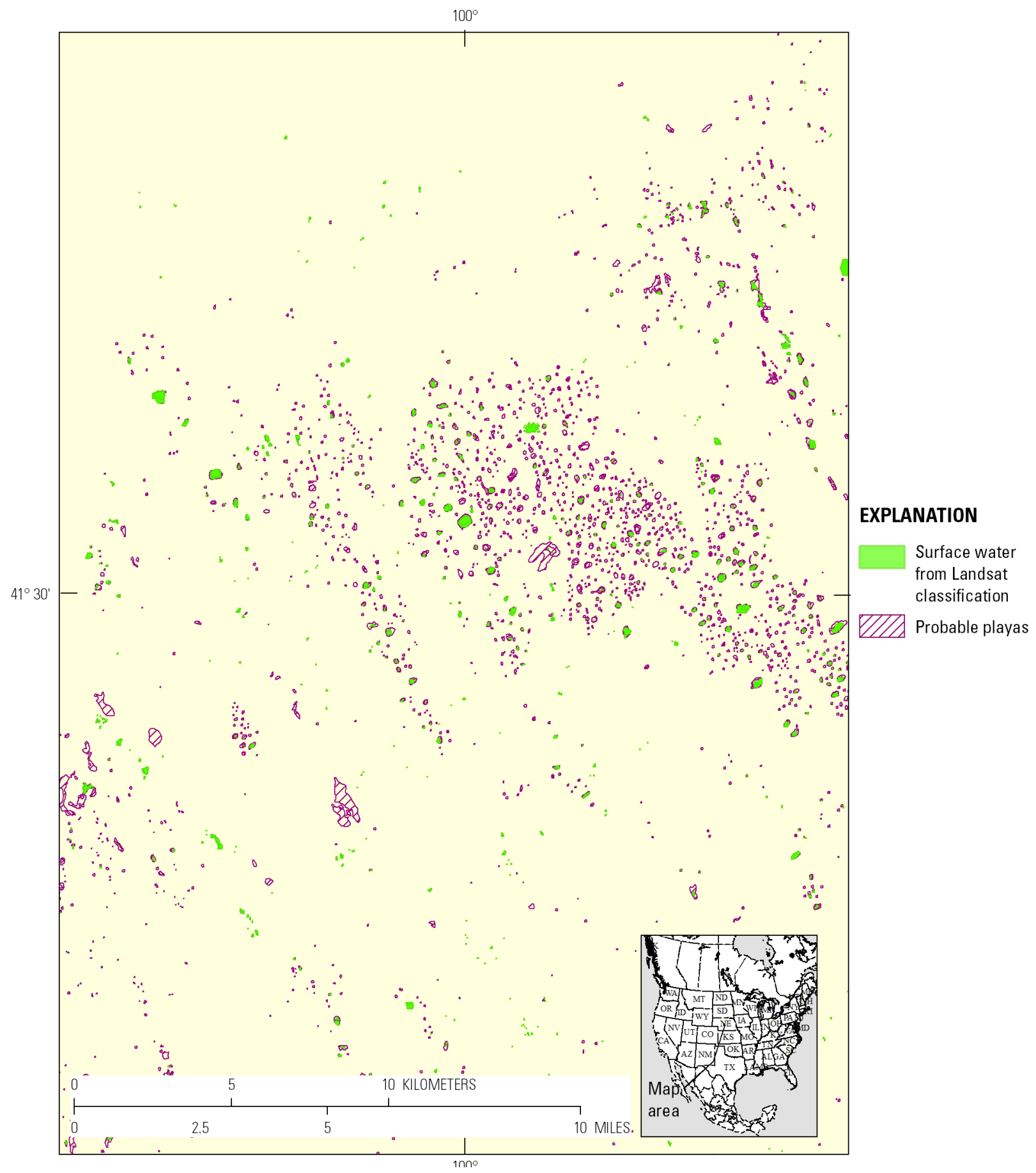

Figure 12. Map showing an enlarged view of a distribution of surface water and probable playas in part of eastern Nebraska within the Great Plains Landscape Conservation Cooperative (GPLCC), in the spring of 2008. Probable playas (purple) and surface water from Landsat (green) are shown. This figure demonstrates the complex pattern of habitat availability created by intermittent inundation with water even in this relatively wet year. Nebraska Historic Wetlands (probable playas) from Rainwater Basin Joint Venture (2014). 


\section{Conclusions}

Based on these results, spatial and temporal patterns in inundation of ephemeral playa wetlands are highly variable among years and within years, and therefore the distribution of associated wetland habitats is also highly variable. We discovered relatively low rates of inundation of playas across the GPLCC region and within sub-units (states, in this case). Because of the importance of State boundaries to the GPLCC Partnership and for regional conservation planning and implementation, inundation summaries for probable playas were estimated in each state and help to demonstrate differences in rates and patterns across the GPLCC region (table 2). Comparison of GPLCC-wide calculations (table 1) with state-level calculations (table 2) indicates that, while 6-7 percent of all playas in the region were wet each season, some states typically exceeded this rate in all (N. Mex., Tex.) or some (Colo., Nebr., Okla.) years. Estimates for Kansas were consistently below this level, and estimates for Nebraska and Oklahoma exceeded the average in only 1 year. The amount of the potential-playa area that was inundated during our survey years (percent area; table 3) presented a similar story of a highly variable distribution and size of inundated wetlands. These results indicated that realized inundation was well below the capacity of the landscape as indicated by maps of potential playas. Thus, even when holding water, the observations here indicated the area of available open-water habitats, for waterfowl, for example, was below the potential capacity described by wetland maps. Although precise climate histories have not been analyzed here, comparison of inundation rates with precipitation summaries from the National Drought Mitigation Center (2015) (table 4, fig. 2) showed an imperfect fit between these data; finer spatial-resolution precipitation indices could be developed to improve potential relations between these variables for future analyses. Importantly, the roles of land use, topography, and soil conditions are known to influence inundation of these surface-water-fed wetlands, so accurate representation of these covariates could improve future analyses. Our results help to refine perspectives on the relative amount and quality of waterfowl and shorebird habitats provided by playas in each state each year and provide a method for indicating spatially and temporally explicit inundation rates, which could be developed as response variables for future assessments. Consideration of local implications may be facilitated by closer review of specific patterns of inundation (for example, see figures 10-12).

While these results provide important insights into the seasonal availability of habitats, additional analyses are warranted. Namely, comparison of inundation percentages among different sub-regions (for example, important waterfowl migration stopover areas, management units, hydrologic units or bio-climatic regions) would allow regional rates and trends to be calculated and compared among other ecologically meaningful units. Importantly, statistical analyses that can help identify contributions of multiple potential drivers, such as climate, land use, and soil conditions, could help inform planning and conservation for water and habitat management. Building on this preliminary work, an opportunity exists to combine and leverage resources from multiple agencies to further develop and incorporate these data, and our wetland classification process, into wildlife habitat research, planning, and regional hydrologic modeling. Integration of future climate scenarios, land cover, land use, and hydrologic modeling could provide much needed information for management, policy, and mitigation decisions related to these ecologically important wetlands and the lands and habitats that encompass them.

\section{References Cited}

Bartuszevige, A.M., Pavlacky, D.C., Burris, Lucy, and Herbener, Kathy, 2012, Inundation of playa wetlands in the Western Great Plains relative to landcover context: Wetlands, v. 32, no. 6, p. 1103-1113.

De'ath, Glenn, and Fabricius, K.E., 2000, Classification and regression trees-A powerful yet simple technique for ecological data analysis: Ecology, v. 81, no. 11, p. 3178-3192.

High Plains Regional Climate Center, 2014, HPRCC climate summaries: Lincoln, Nebr., University of Nebraska, Lincoln, accessed February 2014 at https://hprcc.unl.edu/climatesummaries.php.

Manier, D.J, and Rover, J.R., 2018, Data—Landsat classification of surface water for multiple seasons to model response of playa wetlands to climatic variability across the Great Plains LCC region: U.S. Geological Survey data release, https://doi.org/10.5066/F7MW2GCN.

McKee, T.B., Doesken, N.J., and Kleist, John, 1993, The relationship of drought frequency and duration of time scales, in Conference on Applied Climatology, 8th, Anaheim, Calif., January 17-23, 1993: Anaheim, Calif., American Meteorological Society, p. 179-186.

National Drought Mitigation Center, 2015, Standardized precipitation index for 6 months preceding June 1989, 1996, 2004 and 2008: Lincoln, Nebr., University of Nebraska, Lincoln, accessed January 2015 at http://drought.unl.edu/MonitoringTools/ ClimateDivisionSPI/ArchivedSPIMaps.aspx. 
Office of the Texas State Climatologist, College of Geosciences, 2014a, Drought maps: College Station, Tex., Office of the Texas State Climatologist, College of Geosciences, Texas A\&M University, College Station, accessed February 2014 at http://climatexas.tamu.edu/drought/maps/index.html.

Office of the Texas State Climatologist, College of Geosciences, 2014b, Texas climate monthly reports: College Station, Tex., Office of the Texas State Climatologist, College of Geosciences, Texas A\&M University, College Station, accessed February 2014 at http://climatexas.tamu.edu/products/texas-climate-bulletins/index.html.

Oklahoma Climatological Survey, 2014, Annual summaries: Norman, Okla., University of Oklahoma, accessed February 2014 at http://climate.ok.gov/index.php/climate/annual_summaries/reports_summaries.

Playa Lakes Joint Venture, 2014, Probable playa wetlands dataset, version 4: Playa Lakes Joint Venture, accessed July 2014, at http://pljv.org/for-habitat-partners/maps-and-data/maps-of-probable-playas/.

Rainwater Basin Joint Venture, 2014, Nebraska historic wetland mask, developed for rainwater basin wetland inundation decision support system guide 2013: Rainwater Basin Joint Venture, accessed March 2014 at www.sciencebase.gov/catalog/ item/54ff2673e4b02419550dec1c.

Water resources data system and Wyoming State Climate Office, 2014, Percentage of Laramie County, Wyoming in each drought category by week: Laramie, Wyo., University of Wyoming, accessed February 2014 at http://www.wrds.uwyo.edu/ drought/timelines/LaramieCoDroughtTimeline.html.

Western Regional Climate Center, 2015, Drought monitoring: Reno, Nev., Western Regional Climate Center, accessed January 2015 at https://wrcc.dri.edu/Water/drought.php. 



\section{$\frac{1}{4}$}

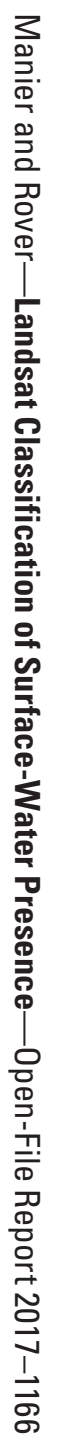

